19 "Plays and Players," The Des Moines Sunday Register, 21 May 1911, p. 44.

${ }^{20}$ Ibid., 8 Oct. 1911 , p. 4.

${ }^{2}$ Ibid., 7 Sept. 1913, p. 4.

${ }^{22}$ The Des Moines Register and Leader, 7 Sept. 1914, p. 9.

${ }^{23}$ Ibid.

${ }^{24}$ The Des Moines Register and Leader, 28 Sept. 1914, p. 9.

${ }^{25}$ Ibid., 12 Oct. 1914 , p. 7.

${ }^{26}$ Ibid., 30 Nov. 1914, p. 8.

${ }^{27}$ Ibid., 18 Jan. 1915, p. 8.

${ }^{28}$ Ibid., 23 Aug. 1915, p. 10.

${ }^{29}$ Ibid., 30 Aug. 1915, p. 8.

${ }^{30}$ Ibid., 18 Oct. 1915 , p. 7.

${ }^{31}$ Ibid., 25 Oct. 1915 , p. 9.

32"Stories and Notes of Photo Plays and the Theatre," The Des Moines News, 28 Nov. 1915, p. 12.

${ }^{33}$ The Des Moines Register and Leader, 29 Nov. 1915, p. 6.

${ }^{34}$ The Des Moines News, 29 Nov. 1915, p. 3.

${ }^{35}$ The Des Moines Daily Capital, 29 Nov. 1915, p. 5.

${ }^{36}$ The Princess Theater Bulletin, 13 Feb. 1916, p. 1. 1916, p. 44.

${ }^{37}$ "Plays and Players," The Des Moines Sunday Register, 28 May

${ }^{38}$ The Princes Theater Bulletin, 12 Sept. 1926, p. 2.

${ }^{39}$ Ibid., 3 Oct. 1926, p. 3.

\title{
Works Consulted
}

The Princess Theater Bulletins, Celia Coggswell Theatre Collections, Iowa State Historical Library, Des Moines, 1909-29.

Julius Cahn's Official Theatrical Guide, Iowa Theatre Collections, Iowa

State Historical Library, Des Moines, 1908-09.

The Des Moines Sunday Register, Des Moines, 1909-27.

The Des Moines Register and Leader, Des Moines, 1909-19.

The Des Moines Daily Capital, Des Moines, 1909-18.

The Evening Tribune, Des Moines, 1909-18.

The Des Moines News, Des Moines, 1909-18.

\section{Early Iowa and Copperhead Journalism}

By David L. Lendt

$M r$. Lendt has been assistant to the vice-president for information and development at Iowa State University since 1967. He received his B.S. degree in technical journalism from Iowa State in 1960 and his M.A. degree in history in 1971. The following article is based upon research which Mr. Lendt did for his book-length thesis, Demise of the Democracy: The Copperhead Press in Iowa. Mr. Lendt is also presently pursuing further graduate work in the College of Education at Iowa State.

In more than a century's study of its causes and results, 
the Civil War has undergone interpretation and reinterpretation and revision upon revision. Iowa's Copperheads, however, have been left virtually untouched; their philosophies and deeds have gone largely unexamined. And their legacy remains an unsavory one, tainted with treason, clouded in violence.

Because the thrust of the Copperhead movement erupted in the Middle West, in the states of Ohio, Indiana, Michigan, Illinois and Wisconsin, the Copperhead philosophy also found expression in Iowa and the story of the Copperhead press became a significant part of the state's history. Iowa's opponents of Abraham Lincoln's administration and its prosecution of the war against the southern states left a rich vein of Copperheadism in what remain of the antiwar newspapers published in the state during the years from approximately 1856 until 1870.

Early Iowa newspapers were exponents of early Iowa's way of life, its politics, its society, its geographical interests, its attitudes on state and national issues. The roots of the state's Copperhead press are buried in the early days of Iowa's statehood and are entangled in the rude complexities of that frontier culture.

Since 1846, when Iowa was admitted to the Union as the first free state in the Louisiana Purchase, the nation had been struggling with a smoldering sectional controversy over slavery and its extension into the territories. That year David Wilmot, an obscure representative from Pennsylvania, offered an amendment forbidding slavery in any territory acquired from Mexico. The Wilmot Proviso made a routine appropriations bill the center of violent and continual disagreement which constituted the first widespread philosophical division between North and South since the enactment of the Missouri Compromise in 1820. That earlier legislation, submitted by Whig Henry Clay, allowed the admission of Missouri to the Union as a slave state. In order to satisfy free-soil sentiments in the North, Congressional balance was maintained by forming the state of Maine out of the territory of Massachusetts and admitting Maine to the Union as a free state. The Missouri Compromise also provided that any new states formed out of the Louisiana Purchase would be admitted as free states if 
they lay north of thirty-six degrees, thirty minutes north latitude and as slave states if they lay south of that line.

When Iowa became a state, under the provisions of the Missouri Compromise, much of the area within its boundaries remained raw frontier. The newly-admitted state was part of the great trans-Mississippi west which, in the years that followed, experienced rapid growth as the participants in the great westward migration sought new self-esteem and personal wealth on the fertile virgin prairies. When Iowa was organized under a teritorial government separate from Wisconsin territory, of which it had been a part, July 4,1838 , its population was approximately $33,000 .^{1}$ Just two years later, its population had risen to 43,112 , including the residents of a small area now a part of Minnesota. ${ }^{2}$ In 1850, four years after Iowa became the twenty-ninth state, its population had burgeoned to 192,214. By June of 1855 , the population was estimated at 326,000 and it was reported that settlers had purchased a total of $3,278,739$ acres at a maximum price of $\$ 1.25$ per acre. By 1860 , the state claimed 674,913 residents and, a decade later, the population had nearly doubled again to a total of $1,194,020 .^{3}$ A southcentral Iowa editor described the situation from his vantage point in 1856: "Never perhaps has there been such a heavy emigration to this State as the present season; judging as we do from the long trains of wagons which are almost incessantly hoving in sight from the east, and disappearing in the west." 4

That editor and others in the newspaper business, under such conditions of rapid growth, found journalism clumsy, frought with financial risk, yet indispensable. Because many of the early practitioners of the art of neswpapering in Iowa were neither inclined to remain long in one location nor endowed with a sense of history, the extent of the wreckage of newspapers strewn throughout Iowa in the early stages of the nineteenth century heyday of journalistic proliferation will never be known with certainty. For some nineteenth century newspapers in the state no record remains except for their mention in the columns of other newspapers of the same era, or their mention in early histories of the counties where they were published. An unknown number passed into oblivion with the deaths of persons who only remembered them.

Because the newspaper offered the one best means of 
reaching relatively large numbers of persons with information for which many hungered, enterprising publishers established at least one in virtually every Iowa hamlet. Early settlers throughout the West purchased subscriptions to local newspapers in surprising numbers and town developers often subsidized the fledgling newspapers as an effective means of advertising their communities. San Francisco, by the mid-1850's, supported more newspapers than did London ${ }^{5}$ and nearly every Iowa city and town maintained at least two."

Early Iowa's "great barbecue" saw thousands of newcomers fight fate, the elements and each other for territory, for political advantage and, in the bargain, personal influence and prestige which many had been denied elsewhere. The philosophy driving many settlers, including newspapermen, was thinly veiled by the news editors of an eastern Iowa newspaper in their salutatory column written at the time they took charge of the publication: "We have longed to occupy a field untrammeled with the conventionalities of an old and aristocratic society, where we could be recognized as one of the constituent parts of the community, and be permitted to work out our own fortune without a popular prejudice opposing."7

Those early editors were convinced that their newspapers were educational tools on a frontier where reading matter was relatively scarce. They felt that, near the edge of the wave of rapid western expansion, their newspapers were necessary if the public were to have the information it required to make a far-flung democratic government work. With the nation's lines of communication stretched and strained, frontier editors, whether Whig or Republican, Democrat or Independent, felt compelled to provide their readers with the "truth" and to combat the propaganda circulated by the opposition. One editor of the Democratic faith expressed the importance of the press from his side of the political fence: "The Democracy, to be successful, must educate, and the only mode by which the mass of voters acquire their education is through the medium of journalism. . . Thus and only thus can you reach the minds, into which the insidious poison of radicalism has been instilled, by the industrious circulation of Abolition literature, in New York Tribunes, Almanacs,, Uncle Tom's Cabins, etc." 
With few exceptions, the Iowa newspapers of the midnineteenth century practiced the "advocacy journalism," which enjoyed a reincarnation in the late 1960 's. The so-called "new journalism" of the twentieth century was the rule in early Iowa and led inexhorably to numerous instances of overstatement and emotionalism, the symptoms of opinionated news reporting unrestrained. The political opinions of most early editors in the state were unmistakably clear. The editors themselves often held positions of prominence and leadership in their respective political parties and their undisguised views were reiterated in their news columns as well as in the upper left corner of the second page generally reserved for their editorial comments. They made themselves parts of the stories they reported rather than attempt to remain impartial and objective in their quest for truth in the reader's behalf.

In many instances, the men in charge of Iowa's early newspapers were less editors than pamphleteers for the party or organization which provided their upkeep. Their loyalty and integrity, however, are not open to question. Many tenaciously espoused principles in which they believed many years after those principles had become unpopular with the majority of their fellow Iowans.

In other cases, the editor was as likely to label his publication "Democrat," "Republican" or "Independent" if, in his judgment, one would attract more paid-in-advance subscribers than another. There were, however, financial plums for the printer whose political philosophy, good fortune and shrewd planning placed him in support of the party in power rather than in the gray area of political independence. To be named county printer meant to enjoy an automatic increase in business, due to the volume of county orders delivered to the editor's backshop. Political subdivisions were also far better credit risks than many customers who brought their job printing orders into the newspaper office or those who reneged on their overdue subscription payments. Perhaps the journalist's greatest political prize in early Iowa was to be named state printer. In 1858, John Teesdale, editor of the Republican TriWeekly Citizen, and William Porter, editor of the Democratic Tri-Weekly Iowa State Journal, both in the Des Moines capital, 
were nominated by their respective parties for the lucrative office. $^{\circ}$

Although it was an aberration, at least one newspaper in Iowa was published as a hobby by a man who evidently could afford it. In introducing his paper, the editor revealed that "The publication of a paper for our own special gratification and amusement has been a long time dream with us." The paper was the realization of that dream, as evidenced by the fact that it carried no advertising and sought none. ${ }^{10}$ Still others, though probably small in number, sailed under false colors. The Humboldt County True Democrat, for example, from its first issue, was a "true abolitionist" paper."

In the Newspaper Collection of the State Historical Society of Iowa alone there exist records of 198 English-language newspapers published in Iowa during the period from 1856 through 1869. In addition, several foreign-language newspapers thrived in the state during that 14-year period. ${ }^{12}$ A directory of newspapers, published in 1869, listed 198 newspapers being published in Iowa at that time. ${ }^{13}$ The collection of newspapers in the Iowa State Department of History and Archives, last indexed in 1947, includes bound copies of 74 Iowa newspapers published between 1856 and 1869. ${ }^{14}$

In 1971, there are 419 newspapers in the state, although many listed as separate publications are printed by the same publishers. ${ }^{15}$ The 419 newspapers serve a population of 2,825 ,041, according to the 1970 federal census; ${ }^{13}$ a ratio of one newspaper per 6,742 residents. Some measure of the importance of newspapers to early residents of Iowa is reflected by the publication of approximately 198 newspapers for a population of $1,194,020$ in 1870 ; a ratio of one newspaper per 6,030 residents, in spite of the hardships involved.

The nation reached its high point of 17,000 weekly newspapers about 1915. A directory of Iowa newspapers published in 1918 listed 768 weekly and semi-weekly newspapers alone. ${ }^{17}$ In the years since, the ranks of these "community newspapers" have been thinned by half. ${ }^{18}$ The mid-nineteenth century saw the beginnings of a rapid growth trend which "topped out" and reversed itself approximately 60 years later.

The number of newspapers in existence in the Iowa of the 
1850 's and 1860 's is surprising because the state was sparsely settled, with the bulk of its people distributed along the Mississippi River border and the adjoining inland counties and across the southern tiers of counties. ${ }^{19}$ Several of the state's ninety-nine counties had only recently been settled and at least one, Osceola county, near the northwest comer of Iowa, was not settled until $1870 .^{20}$

It is also remarkable that some 200 Iowa newspapers existed during the period between 1856 and 1870 because of the difficulties associated with the frontier publishing business. Primitive transportation, equipment and financial machinery were formidable obstacles to profitable frontier publishing. The partisan editor occasionally had to defend himself physically, as well, from the violent actions resulting from equally primitive frontier attitudes.

Before the Mississippi River was bridged by rail to the Iowa shore, ${ }^{21}$ the transportation of unwieldy presses, type cases and "stones" (the heavy tables upon which the newspaper pages were "made up") was a difficult task in itself. As the years passed, and with them one fledgling newspaper after another, the "equipment" was often purchased from discouraged publishers by those with brighter hopes. Once he had transported his equipment to his land of opportunity, the publisher had difficulty finding suitable housing for himself and his tools of trade. Print shops were begun in log cabins, barns, vacant mills or within any other shelter from the elements. In the midst of an Iowa winter, a printer was likely to discover that his ink had frozen in the overnight cold. Beset with transportation and location problems, the early Iowa editor also had trouble running his equipment efficiently. One printer described the presses generally in use as "one grade better than a cheese press." Printers operated the primitive presses by hand and, under normal conditions, could print one side of a "token" of paper per hour. (A token was ten quires of paper consisting of twenty-four sheets per quire.) Printers ran ink onto the type, between each impression of the press, with rollers covered with a mixture of glue and molasses boiled to a smooth yet spongy consistency. ${ }^{22}$

For all its early progress on several fronts, Iowa, in those 
formative years of its statehood, was notably lacking in state legislation which would establish a uniform currency necessary to facilitate rapid and orderly economic growth. For several years after Iowa became a state, the Democratic party held political sway and its conservative monetary policies were ingrained in the state's laws. This Democratic conservatism, enveloped in a fear of tyrannical federal government, which played a substantial part in the Copperhead movement to come, was expresed in the editorial comment of a Des Moines newspaper in 1858:

Our government is fast becoming an elective monarchy. The doctrine inherited from our ancestors that standing armies are dangerous to the liberties of the people, is repudiated by constant and strenuous efforts to increase the national army. The Federal Government now asks to control all the banking institutions in the States by virtue of some law of Congress. Sinecure offices are created for the purpose of influencing public opinion ... This centralizing influence of the government -the immense increase of our national expenses-the history of slavery propagandism in Kansas, and the complicity of the federal government therewith; the attempt to overthrow the clearest right of self government for the purpose of extending the institutions of slavery, and the efforts to destroy the rights of the States by political decisions of the supreme court, should remind the freemen of Iowa that their political rights are in danger. ${ }^{23}$

Early newspapermen and Iowa entrepreneurs in other fields, unless they held their capital in specie, were likely to have hard times. Because of its hesitant and suspicious monetary policy, Iowa became the "dumping ground" for the uncertain currency of other states. Following the economic panic of 1837, and shortly after Iowa became a separate territory, its government outlawed all banks of issue. The Constitutional Convention of 1857 finally legalized banks of issue and the State Bank of Iowa, which was eventually organized, lasted until 1865 when the owners of the state charter gave it up to incorporate under the new federal banking act. ${ }^{24}$

Early editors and publishers depended heavily upon payment in advance for annual subscriptions to their newspapers in order to gather the interest-free working capital required to sustain their businesses year after year, whether in or out of political favor. In most cases, a year's subscription cost $\$ 2.00$ for a weekly publication, if paid for at the end of the year. 
Prospective subscribers were given the opportunity, however, to receive the paper for a year upon payment of $\$ 1.50$ in advance. Whether in advance or not, frontier readers often paid their bills in live chickens, firewood or some other useful commodity. Others, jaded by their experiences with disreputable newspapermen, refused to pay in advance under any circumstances.

Editors entered and left the hard life of newspapering with such frequency that the mastheads of early Iowa journals were often changed several times each year and, in some cases, within months or weeks. An easterner, Andrew F. Tipton, founded the Mississippi Valley Register in Guttenberg May 19, 1859, with an optimistic assessment of his future:

We are fully aware of the responsibility we are assuming in attempting to publish a paper, in a county where two already exist. We are, however, satisfied, from the fact that Guttenberg contains a population of about 2,000 inhabitants, and is surrounded by a rich and populous county, that a paper can be sustained here. ${ }^{25}$

Six weeks later, June 30 , he had left his dreams on the bank of the Mississippi River and had returned to the East. In January, 1860, Oliver D. Eno became editor of the newspaper Tipton had founded. In his introductory editorial, he freely admitted he was "inexperienced." ${ }^{26}$ By October, he was a candidate for Clerk of the District Court. Each week he published the complete Democratic ticket in the Register, with his name set in type at the bottom of the ticket in the same size as that used for Stephen A. Douglas at the top! With the election over and Eno soundly defeated in his bid for public office, he gave up his editorial chair ten months after he had occupied it and turned to teaching instead. ${ }^{27}$ The troubles of the Register did not end with Eno's departure. Less than a month after the surrender of Fort Sumter, the Register surrendered to poverty. Two years after the optimistic Tipton launched the enterprise, the following note of farewell appeared in the last number of the paper: "Four newspapers are most to [sic] many to get very fat in Clayton County, with present population." ${ }^{28}$

Newspaper finances were also influenced by political fate. Due largely to government printing made available to them, the newspapers allied with the party in power generally had 
an easier time than those who found themselves out of governmental favor. A Democratic editor expressed the situation from his own biased perspective: "We need your support now more than ever. The papers of the opposition are fed from the public trough, and, become obese and gorged, they are far inferior in merit to the Democratic papers that have to struggle bravely for a precarious existence."29 Iowa newspapers of the 1850's and 1860 's continually made similar appeals to the readers in their areas and to subscribers who had failed to pay their bills as agreed. A Bloomfield editor each week named in his editorial column those subscribers who had not "paid up."

In addition to his day-to-day financial difficulties, the frontier editor was faced with natural hazards which could put him out of business overnight. The Council Bluffs Bugle was destroyed twice by fires exactly a year apart. ${ }^{31}$ The State Press in Iowa City was started again after its building collapsed, killing several workers and smashing its machinery. Its editor, in July, 1864, could speak for many in the newspaper business: "The patrons of the PRESS are well aware, that during the last few years it has suffered many changes and vicissitudes; indeed its conductors have experienced all the misfortunes that can fall to the lot of Journalists."32

Perhaps because they shared common hardships, there was a fraternal feeling among newspaper editors and publishers of similar political persuasions. An effective device for keeping in touch was the exchange of newspapers free of charge, a practice which persists among weekly newspapers in Iowa today. As long as the papers were being exchanged, for the news value of common interest to the newspapers' editors, the papers were convenient for passing inexpensive, if quite public, messages among editors. Oliver I. Taylor, editor of the Des Moines News, for example, offered his thanks in public for the exchange service provided by a Burlington paper. "We are indebted to the Burlington Hawk-Eye for a daily exchang $[s i c]$, which gives us the current telegraphic news earlier than we can receive it by any other paper. ${ }^{, 33} \mathrm{~A}$ Copperhead editor publicly chastised a leading Copperhead newspaper: "THE DUBUQUE HERALD.-This paper having cut us off from an exchange, we shall this week return the 
compliment."34 When he could, an editor would "steal" a day from his labors and travel several miles to the office of his counterpart in a nearby community. He would return to "write up" his trip, exhorting his readers to show the dynamism and progressive attitudes he had encountered while away and to support the local newspaper as well as his fellow editor's publication was being supported. ${ }^{35}$

For all their weaknesses, frontier editors contributed an important strength to early Iowa; the presence, in even small and remote communities, of more than one newspaper and more than one editorial view of public matters. The public benefited from the availability of differing opinions, even if most such expressions were emotionally, and many inaccurately, expressed. As the number of newspapers declined in Iowa, due primarily to the influence of other media, weeklies which were aggressive competitors became "twin-weeklies" written by the same editors and printed beneath the same roof. As the multiplicity of newspapers became a luxury which no longer could be economically justified, other newspapers, which were neither bought out by stronger competitors nor merged by them, died stubbornly; but they died. Thus, from nativity to death, a host of Iowa newspapers lived shorter lives than most nineteenth century Iowans. In the brief lives allotted them, however, they lived to the hilt. Although some papers later labeled as Copperhead sheets were among those which died in their infancy, the descendants of other Copperhead papers are still thriving in Iowa today, their Civil War pasts virtually forgotten or ignored.

\section{NOTES}

${ }^{1}$ Guthrie Sentinel (Panora, Iowa), January 25, 1856.

${ }^{2}$ L. Dale Ahern, ed., Iowa Official Register (Des Moines: State of Iowa, 1969), p. 529.

${ }^{3}$ Ibid.; Guthrie Sentinel, loc. cit.

${ }^{4}$ Guthrie Sentinel, May 31, 1856, p. 2, col. 1.

${ }^{5}$ Ray Allen Billington, America's Frontier Heritage (New York: Holt, Rinehart and Winston, 1966), p. 80.

${ }^{6} \mathrm{~L}$. O. Cheever, comp., Newspaper Collection of the State Historical Society of Iowa (Iowa City: The State Historical Society of Iowa, 1969), pp. 11-96. 

col. 1 .

${ }^{7}$ The Blackhauk Courier (Waterloo, Iowa), January 18, 1859, p. 2,

${ }^{8}$ The State Press (Iowa City, Iowa), February 3, 1864, p. 4, col. 1.

${ }^{\circ}$ Tri-Weekly Iowa State Journal (Des Moines, Iowa), January 15, 1858.

${ }^{10}$ The Shady Side (Keosauqua, Iowa), October 27, 1871.

${ }^{11}$ Humboldt County True Democrat (Humboldt, Iowa), June 1, 1866 , p. 2, col. 1 ; January 25,1867 , p. 2 , col. 1.

${ }^{12}$ Cheever, loc. cit.

${ }^{13}$ The American Newspaper Directory (New York: George P. Rowell and Co., 1869), pp. 31-36.

${ }^{14}$ Edward F. Pittman, comp., Index to Bound Newspapers in Iowa State Department of History and Archives (Des Moines: State of Iowa, 1947), pp. 7-34.

${ }^{15}$ Ahern, op. cit., p. 529.

${ }^{16}$ U. S. Bureau of the Census, 1970 Census Population: Iowa Advance Report PC(V1)-17 (Washington: Government Printing Office, 1970), p. 3.

${ }^{17} \mathrm{~N}$. W. Ayer and Son's American Newspaper Annual and Directory (Philadelphia: N. W. Ayer and Son's, 1918), pp. 277-320.

${ }^{18}$ Dale Elwood Boyd, "North Central Iowa Community Newspaper Problems: Their Identinfication and a Proposal for Solution," (Ames: Iowa State University, 1970), Reproduction of typewritten manuscript of unpublished Master of Science thesis, pp. 1-4.

${ }^{19}$ Census Board, The Census Returns of the Different Counties of the State of Iowa, for 1856 (Iowa City: Crum and Boye, Printers, 1857); Iowa Census Returns, Vol. 67, pp. 1045-1081, Iowa State Department of History and Archives, Des Moines.

${ }^{20}$ Katherine Young Macy, Notes on the History of Iowa Newspapers, 1836-1870, University of Iowa Extension Bulletin No. 175, July 1, 1927, p. 83; Ahern, op. cit., p. 479.

${ }^{2}$ 'Erling A. Erickson, "A History of Frontier Banking in Iowa, 18361865," Manuscript submitted to Iowa State University Press, Ames, 1970, p. 138. Erickson reports that, in 1856 , a 5,832-foot rail bridge was constructed at Davenport, for the first time connecting internal Iowa with the Chicago railhead; Des Moines Register, "Picture Magazine," November 15,1970, p. 5 . This article reports that the Keokuk Municipal Bridge, which is still being used, was not built until 1869-1870.

${ }^{22}$ Macy, op. cit., p. 7.

${ }^{23}$ Tri-Weekly Iowa State Journal, January 15, 1858.

${ }^{24}$ Erickson, op. cit., p. 18.

${ }^{25}$ Mississippi Valley Register, (Guttenberg, Iowa), May 19, 1859, p. 2 , col. 1.

${ }^{26}$ Missisippi Valley Register, January 26, 1860, p. 2, col. 1.

${ }^{27}$ Mississippi Valley Register, November 15, 1860, p. 2, col. 1.

${ }^{28}$ Missisippi Valley Register, May 10, 1861, p. 2, col. 1.

${ }^{20}$ The State Press, November 23, 1864, p. 2, col. 1. 

col. 1.

${ }^{30}$ Ward's Own (Bloomfield, Iowa), July 9, 1857-April 18, 1858, p. 2,

${ }^{31}$ Macy, op. cit., p. 90.

${ }^{32}$ The State Press, July 6, 1864, p. 2, col. 1.

${ }^{33}$ Des Moines News (Keosauqua, Iowa), July 1, 1859, p. 2, col. 1. col. 1.

${ }^{34}$ The Weekly Courier (Muscatine, Iowa), April 15, 1864, p. 334,

${ }^{35}$ The State Press, February 24, 1864, p. 4, col. 2.

\title{
The Quest for Community in Rural Iowa: NEIGHBORHOOD LIFE IN EARLY MIDDLEBURG HISTORY
}

\author{
by \\ Gary Koerselman
}

Dr. Koerselman is a native of Sioux City, Iowa. He received his Ph.D. from Northern Illinois University in June of 1971 and specializes in twentieth-century American studies.

\section{Introduction}

Last year Dr. Koerselman published an article in the ANNALS entitled "The Church and Community Life in Early Middleburg History." Middleburg is a small hamlet located in the middle of Sioux County in Northwest Iowa. In last year's article, Dr. Koerselman contended that Middleburg's development was unique because the church filled the social vacuum created by the absence of such institutions as banks, elevators, and railroads. Also, Middleburg was never formally incorporated.

In the following article Dr. Koerselman analyzes the social impact of the "neighborhood" on agrarian life in Middleburg around the turn of the century.

Before historians can fully appreciate and understand the framework of agrarian society in America, they must consciously attempt to describe and define the functions of such institutions as the "neighborhood." Such an investigation is wrought with problems of definition and measurement, of course. Activities predicated upon the impulse of neighbor- 
Copyright of Annals of Iowa is the property of State of Iowa, by \& through the State Historical Society of Iowa and its content may not be copied or emailed to multiple sites or posted to a listserv without the copyright holder's express written permission. However, users may print, download, or email articles for individual use. 